\title{
Global Stratotype Section and Point for base of the Sinemurian Stage (Lower Jurassic)
}

\author{
1. Staatliches Museum fuer Naturkunde, Rosenstein 1, D-70191 Stuttgart, Federal Republic of Germany. \\ 2. Department of Geological Sciences, University of Plymouth, Drakes Circus, Plymouth PL4 8AA, United Kingdom.
}

\begin{abstract}
The Global Stratotype Section and Point for the base of the Sinemurian, the second stage of the Lower Jurassic (Lias), is exposed in the cliff north of the village of East Quantoxhead, around $6 \mathrm{~km}$ east of Watchet, in the administrative district of West Somerset, southwestern England. The boundary level is $0.90 \mathrm{~m}$ above the base of Bed 145 coinciding with the first appearance of the genera Vermiceras (V. quantoxense, V. palmeri) and Metophioceras (M. sp. indet. 1). The basal ammonite assemblage of the Sinemurian in the GSSP is earlier than all other assemblages known elsewhere in Europe. In Europe, a stratigraphical gap between both stages is generally present. Correlation with other faunal provinces is possible using the first appearance of Metophioceras s. str.
\end{abstract}

\section{Introduction}

The Sinemurian, second stage of the Jurassic System, was introduced by d'Orbigny in 1842 . He derived the term from Sinemurum Briennense castrum, the Roman name for Semur-en-Auxois in eastern France, a small town whose environment is rich in fossils of early Sinemurian age. The succession in this historical type area is, however, now known to be incomplete (Corna and Mouterde, 1988) and not, therefore, fulfilling the requirements for a suitable stratotype section (Remane et al., 1996).

A later interpretation of a type area was based on the subdivision of the Sinemurian into ammonite zones and subzones (in a chronostratigraphical sense) as originally established by Oppel (1856-1858) and, ultimately, the standard scheme of Donovan in Dean et al. (1961). The type area of the lowermost subzone of the Sinemurian, the Conybeari Subzone, is in sw England. Consequently, Donovan (in Morton, 1971) proposed the section in the coastal cliffs west of Lyme Regis (Devon-Dorset coast) as a stratotype for the Sinemurian Stage.

A later study (Palmer, 1972; see also Whittaker and Green, 1984) revealed a sequence across the Hettangian/Sinemurian boundary on the West Somerset coast, between Watchet and Stolford, nearly five times thicker than that near Lyme Regis. Moreover, the ammonite succession in the latter area is more complete than any known elsewhere in Europe and the earliest Sinemurian-type ammonite fauna there predates that at Lyme Regis and all others known from the base of the Sinemurian in the Northwest European Province (Bloos and Page, 2000). This exceptionally complete sequence, as best exposed north of East Quantoxhead, was proposed as the GSSP for the base of the Sinemurian Stage by Page (1995).

Among the known sections across the Hettangian/Sinemurian boundary elsewhere in the world where sedimentation is believed to be continuous, the GSSP at East Quantoxhead offers the most com- plete succession of relatively well preserved ammonites. This section best meets the requirements of the International Commission on Stratigraphy (ICS) for a stratotype section (GSSP). It has therefore been accepted as a GSSP by the Sinemurian Boundary Working Group, the ISJS and the ICS - almost unanimously - and was finally ratified by IUGS in August 2000.

\section{Location and general remarks}

The "East Quantoxhead" GSSP is situated in the West Somerset administrative district of the county of Somerset (in sw England, about $6 \mathrm{~km}$ east of the town of Watchet; U.K. National Grid refer-

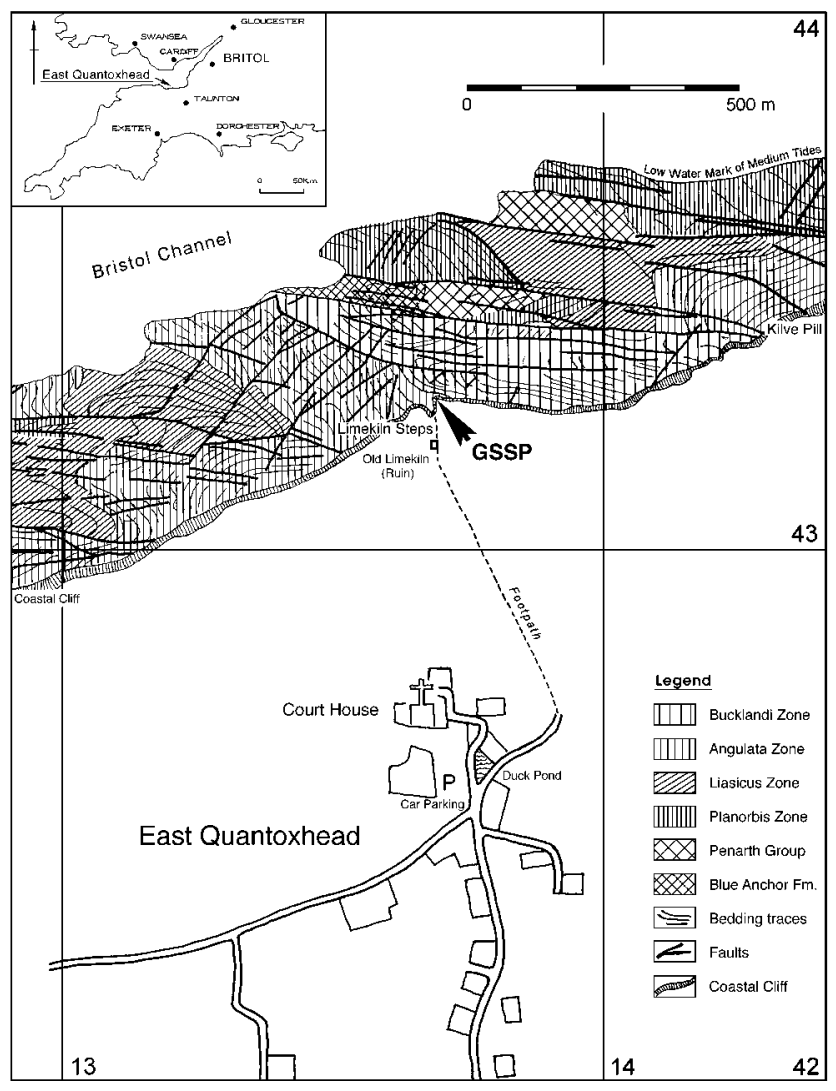

Figure 1 Location of the GSSP for the base of the Sinemurian (= base of Bucklandi Zone) on the West Somerset coast north of East Quantoxhead at "Limekiln Steps" with geology of the foreshore; beach deposits are omitted. Towards southwest from the GSSP the base of the Sinemurian is higher in the cliff (see Figure 3), towards east from the GSSP it is in the subsurface. Source: British Geological Survey, 1: 50 000, Weston-Super-Mare (England and Wales Sheet 279, Solid and Drift Edition), herein Six-Inch Maps of the cliff and intertidal area east of Watchet as insets. 


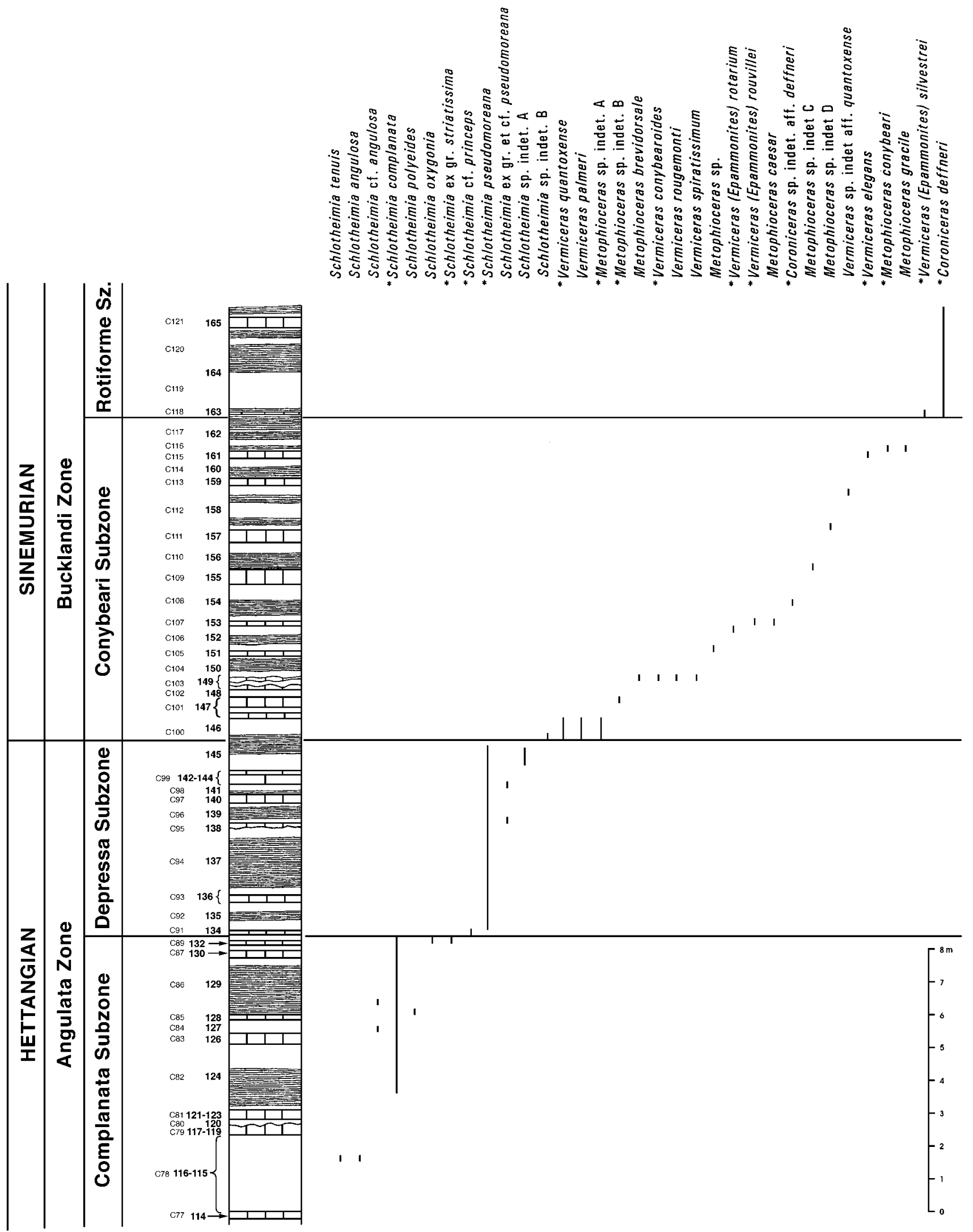

Figure 2 Section of the GSSP for the base of the Sinemurian at the coastal cliff north of East Quantoxhead, West Somerset, sw England. Indicated are the bed numbers of Palmer (1972; C-numbers on the left) and of Whittaker and Green (1983; numbers on the right). In Figures 3-7 only the bed numbers of Whittaker and Green are used.

White: marl; dark: bituminous shale; vertically hatched: limestone. In Beds 115-116 the bituminous shale is not indicated because no exact measurement was possible. Note that the stage boundary is within a homogeneous lithological unit (bituminous shale).

*Index species of biohorizons. Some forms are not yet named. 
ence ST 137 443. The section is in a coastal cliff $500 \mathrm{~m}$ north of the Court House, East Quantoxhead, where iron steps (the "Limekiln Steps" in Palmer, 1972, named after an adjacent old limekiln) give access to the beach (Figures 1, 3). A footpath (c. $800 \mathrm{~m}$ ) leads from a car parking near the Court House to the locality.

The boundary section is immediately below and on either side of the mentioned iron steps (Figures 1, 3), and easily accessible in the lowest part of the cliff. Due to a gentle dip to the north and east, the sequence is also well exposed on the foreshore, where extended exposures of bedding surfaces offer favourable conditions to sample bed by bed.

Though numerous faults exist along the Somerset coast, the stratotype is situated within a single major fault block with an extended and continuous range of strata without further tectonic complications (Figure 1).

The access to the site is unrestricted and the section is continuously exposed to the sea and will always remain open. The locality is within a Site of Special Scientific Interest (SSSI) and has been protected under U.K. nature conservation law from 1986 (Page et al., 2000).

\section{Facies}

The key part of the coastal section comprises about $27 \mathrm{~m}$ of strata which include the upper part of the Angulata Zone and the lower part of the Bucklandi Zone. This sequence, including the stage boundary, is entirely in Blue Lias facies (see Palmer, 1972; Whittaker and Green, 1983).

The sediments are fine-grained throughout. There are no indications of deposition in shallow water or of nearshore environments despite the proximity of Devonian rocks which form the Quantock Hills, south of East Quantoxhead.

The Blue Lias typically shows sedimentary cycles which, from the base upwards, comprise: bituminous shale - marl - limestone - marl (Figure 7). The boundaries between these cycles, at the base of the bituminous shale units, are very distinct and may be accentuated by a thin pavement of fine reworked shell debris; the upper boundary of the bituminous shale is transitional into the overlying marl.

The most variable component of the cycles is the limestone unit which sometimes may comprise two or more beds, or may be absent, represented only by marl. The cementation of most of the limestones was not early in diagenesis as ammonites are usually more or less crushed. The sediments which formed the marl and limestone units were probably originally not very different and the cycles may therefore have comprised at first only two elements: finely laminated bituminous shales (indicating anoxic conditions) at the base grading upwards into aerated mud sediments. It may be that one or more levels in this mud had a slightly higher content of calcareous particles and that these levels were later transformed into limestone beds by cementation.

The break of sedimentation at the top of the cycles must have been rather short, shorter than the time intervals which can be recognized by biostratigraphic means (i.e. biohorizons).

In comparison with the sequence near Lyme Regis (Devon - Dorset coast) which was formerly proposed as a type section, the Blue Lias limestones in Somerset are often darker, more porcellaneous in character, more homogenous, and have less distinct burrows and fewer Liogryphaea. The thickness of the Blue Lias on the Somerset coast is greater than on the Devon coast and, in general terms, water depth must have been greater and subsidence faster in Somerset.

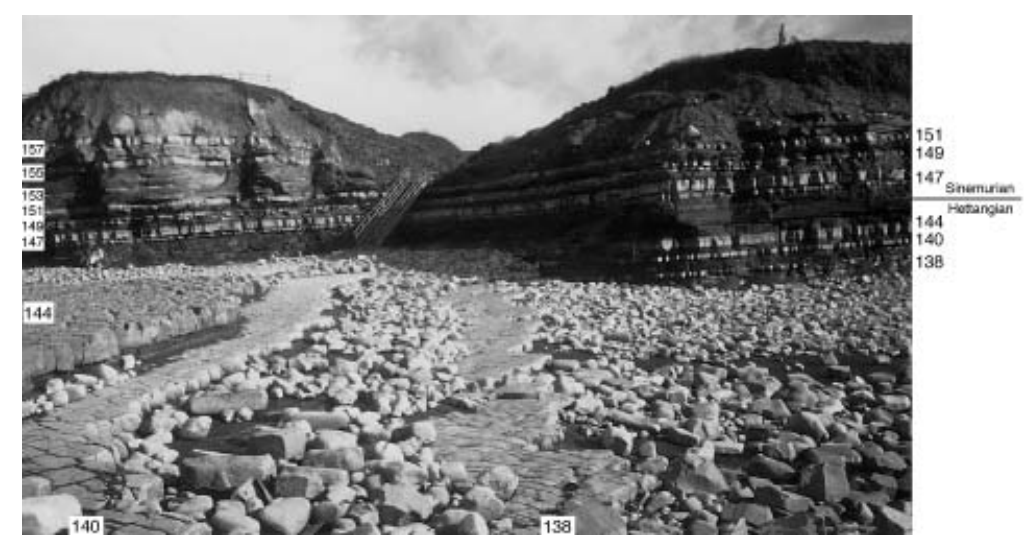

Figure 3 Coastal cliff north of East Quantoxhead, part immediately at "Limekiln Steps" (iron steps in the centre background) with the base of the Sinemurian. The stratotype section (GSSP) is near the left margin of the foto. In the upper part of the cliff the Lias is weathered and overlain by Quaternary sediments. View southeastwards; bed numbers of Whittaker and Green (1983), same as in Figure 2.

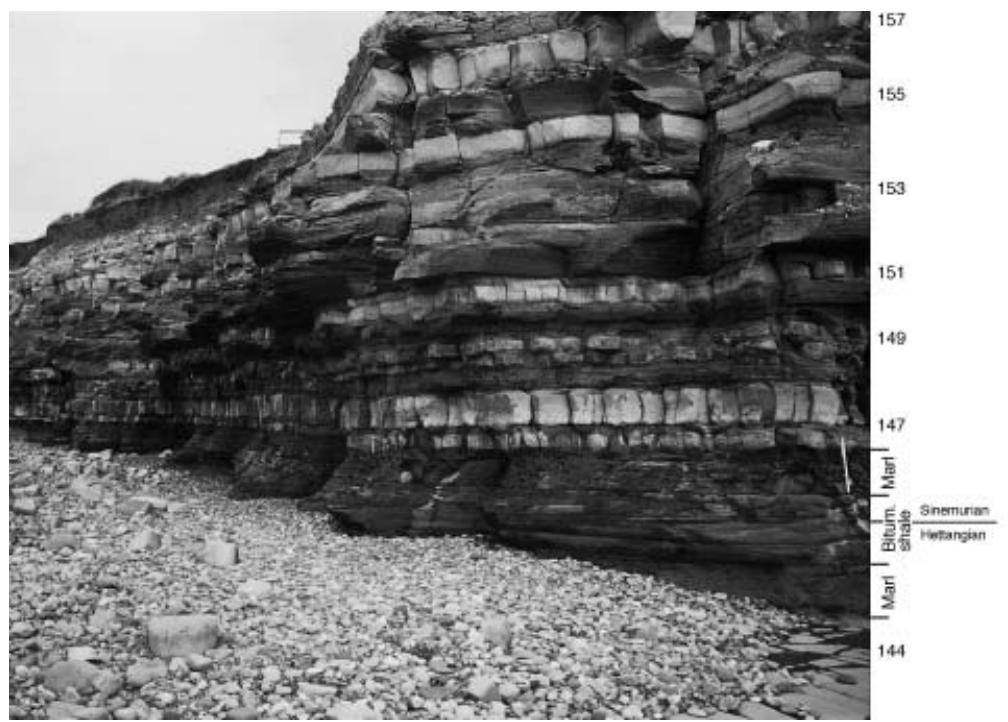

Figure 4 Stratotype section (GSSP) for the base of the Sinemurian at "Limekiln Steps" (eastern side) in detail (location see figures 1 and 3). Here the stage boundary is most readily accessible in the cliff. This situation occurs again nearby in the eastern continuation of the cliff (to the left) towards "Whaleback Rock" (see Figure 6). Scale: $0.60 \mathrm{~m}$.

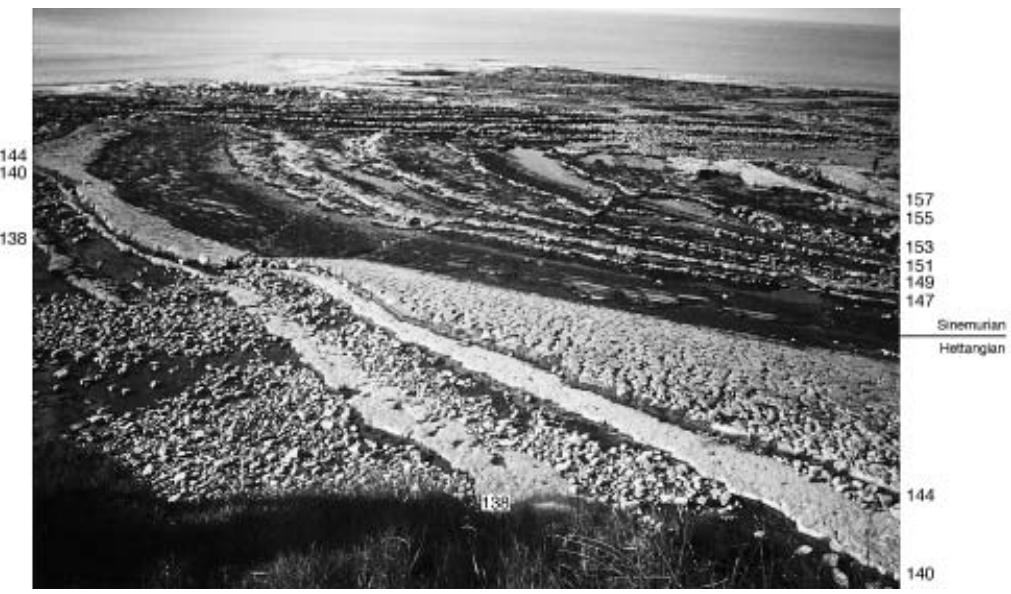

Figure 5 View from the cliff immediately west of "Limekiln Steps" to the foreshore (in northeastern direction) during low tide. The slight inclination of the beds provides broad outcrops which facilitate collection of fossils; the seaweed is usually reduced during winter storms. Bed numbers same as in Figures 2 and 3. 


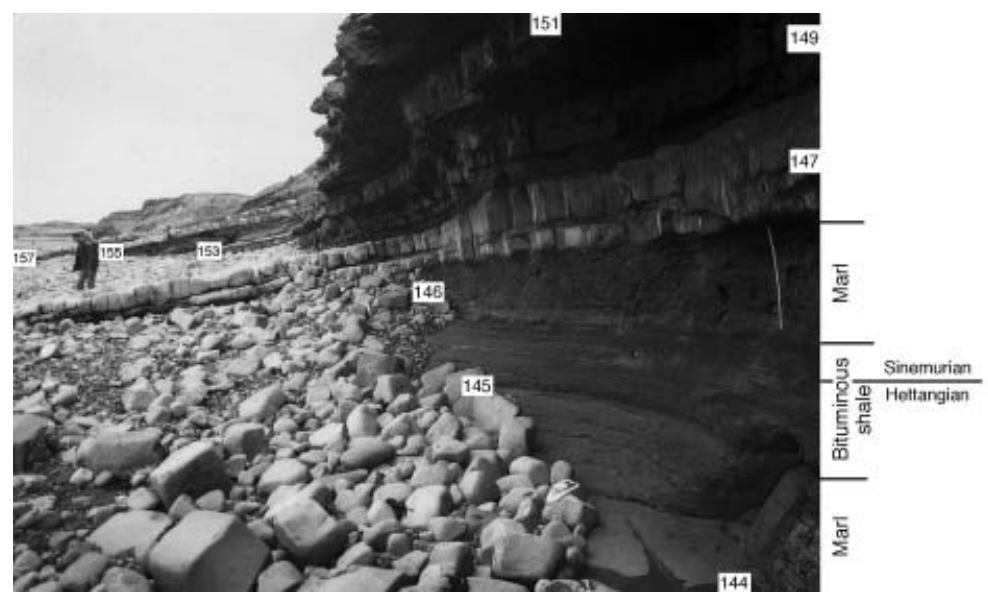

Figure 6 The Hettangian/Sinemurian stage boundary between "Limekiln Steps" and "Whaleback Rock" where the different lithologies are seen most distinctly. Bed numbers same as in Figures 2 and 3. View eastwards towards "Whaleback Rock". Scale: $0.60 \mathrm{~m}$.

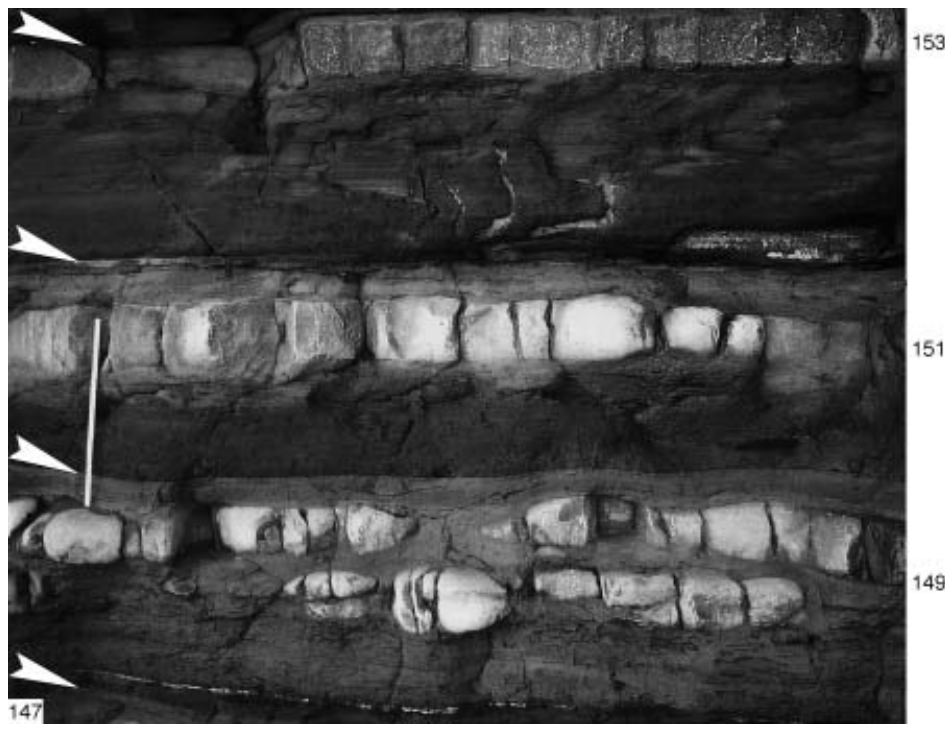

Figure 7 Blue Lias facies in the cliff near "Limekiln Steps", north of East Quantoxhead; the typical cycles are well visible. The cycle boundaries are indicated by white arrows. Bed numbers same as in Figures 2 and 3. Scale: $0.60 \mathrm{~m}$.

\section{Sequence of strata}

The studied sequence, $27 \mathrm{~m}$ thick, comprises an Upper Hettangian to Lower Sinemurian sequence (see Figure 2). The Upper Hettangian includes part of the Complanata Subzone (c. $7.8 \mathrm{~m}$ ) and a complete Depressa Subzone sequence $(5.60 \mathrm{~m})$; the Lower Sinemurian consists of a complete Conybeari Subzone $(9.85 \mathrm{~m})$, overlain by part of the Rotiforme Subzone $(3.80 \mathrm{~m})$. The continuation of the section higher into the Rotiforme Subzone was not examined in detail, but the subzone is known to be complete, the base of the Bucklandi Subzone (with Vermiceras scylla) being present in the cliff near Kilve Pill.

The studied part of the Complanata Subzone contains species of Schlotheimia characteristic of this subzone in the NW European Province (Figures 2, 8). In the overlying Depressa Subzone the diversity of Schlotheimia is, in contrary, very low.

In the Conybeari Subzone (Figures 2,9) there is a rapid change of arietitid faunas, with nine biohorizons distinguishable, four of which are known also from other parts of the NW European Province. Metophioceras conybeari, index species of the Conybeari
Subzone, occurs in the uppermost biohorizon of the subzone (Figure 2). The third biohorizon (Figures 2, 4) from below (in bed 149) is normally the lowermost of the Sinemurian in the NW European Province; the faunas below at East Quantoxhead are lacking elsewhere, including near Lyme Regis.

\section{Boundary level}

The level chosen corresponds with the striking change in the ammonite fauna from the genus Schlotheimia (mainly $S$. pseudomoreana) in the latest Hettangian to the arietitid genera Vermiceras (V. quantoxense, V. palmeri) and Metophioceras in the earliest Sinemurian. This change is characteristic of the Northwest European Province and on this basis, the boundary between the Hettangian and Sinemurian stages has been defined ever since Renevier's first proposal of the former stage in 1864. Normally, the two ammonite groups are not found together but, uniquely, in Somerset, specimens of Schlotheimia (Schloth. sp. indet. B) and the first arietitids

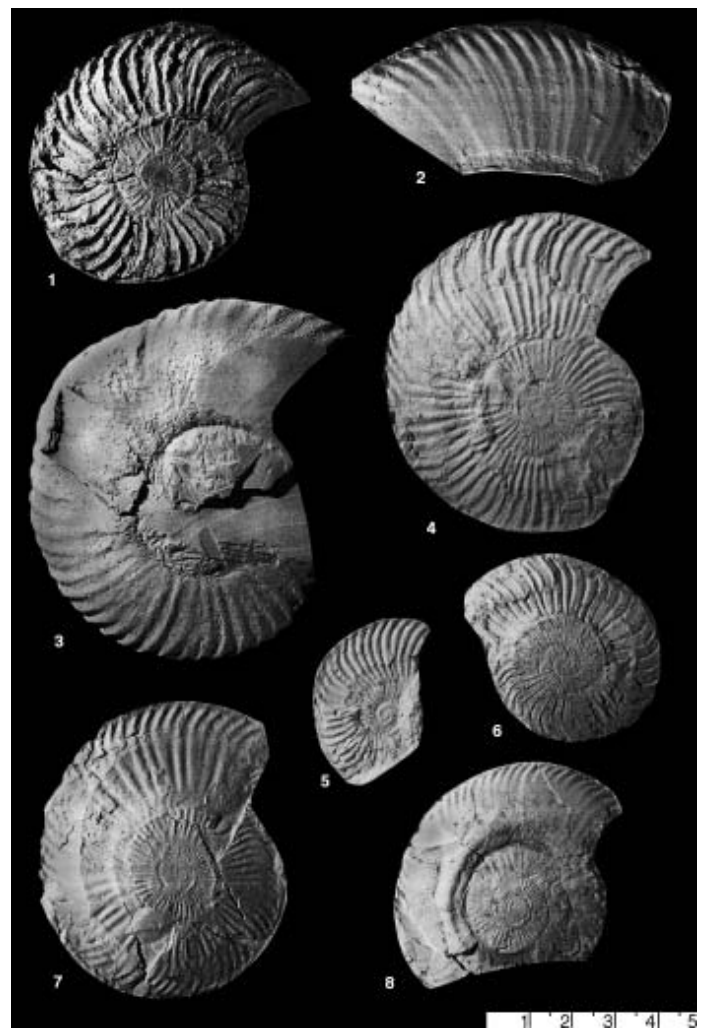

Figure 8 Characteristic species of Schlotheimia in the uppermost Hettangian at East Quantoxhead (from Bloos and Page, 2000). Scale: $5 \mathrm{~cm}$. The specimens are housed in the Sedgwick Museum Cambridge. Depressa Subzone:

1. Schlotheimia sp. indet. A, co-occurring with $S$. pseudomoreana Spath; base of Bed 145 (top of Hettangian) (SMC X29321); 2. Schlotheimia. pseudomoreana Spath, fragment of body chamber; base of Bed 145 (top of Hettangian) (SMC X29322); 3. Schlotheimia cf. princeps S. Buckman, probably indicating the horizon of $S$. depressa; upper surface of Bed 134 (SMC X29323). Complanata Subzone (upper part): 4. Schlotheimia ex gr. striatissima (Quenstedt); Bed 133 (top of the Complanata Subzone) (SMC X29324); 5. Schlotheimia oxygonia Lange; Bed 99 (SMC X29325); 6. Schlotheimia angulosa/phobetica group; Bed 99 (SMC X29326); 7. Schlotheimia complanata Koenen, Bed 95 (SMC X29327); 8. Schlotheimia complanata polita Lange; Bed 95 (SMC X29328). 


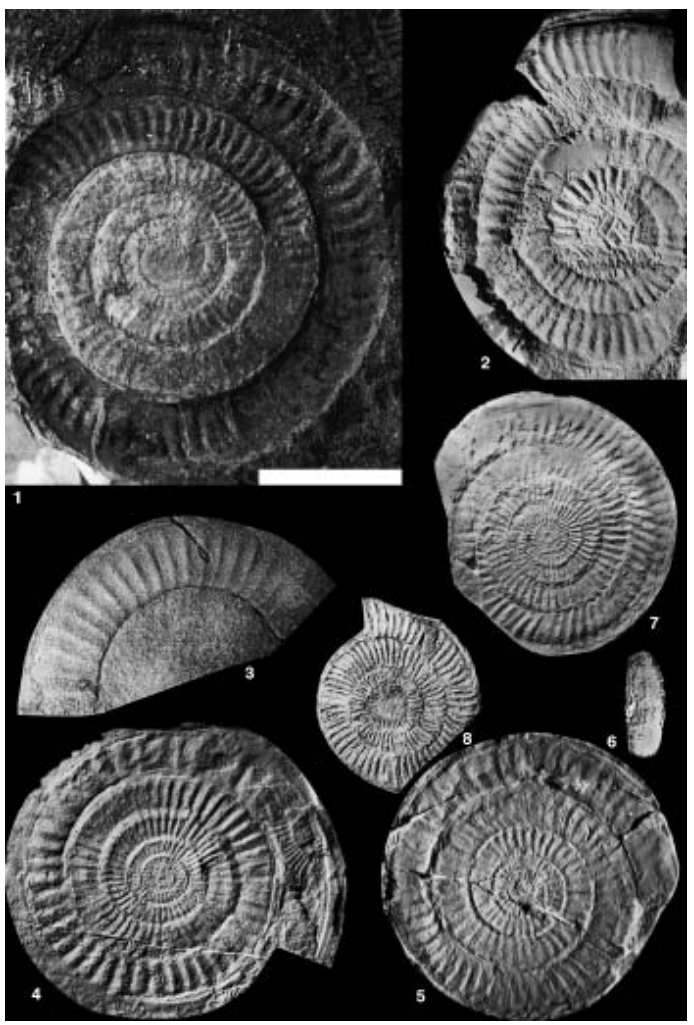

Figure 9 Characteristic species from the lowermost Sinemurian at East Quantoxhead (from Bloos and Page, 2000). The specimens are housed in the Sedgwick Museum Cambridge. Conybeari Subzone: 1. Metophioceras brevidorsale (Quenstedt); Bed 149 (SMC X29329). Scale: $10 \mathrm{~cm} ; 2$. Vermiceras rougemonti (Reynès), Bed 149 (SMC X29330). Same scale as Figure 8; 3. Metophioceras sp. indet. A; Bed 145, top of bituminous shale (basal assemblage of the Sinemurian) (SMC X29331). Same scale as Figure 8; 4. Vermiceras quantoxense Bloos and Page, 2000, holotype; Bed 145, top of bituminous shale (basal assemblage of the Sinemurian) (SMC X29332). Same scale as Figure 8; 5. Vermiceras palmeri Bloos and Page, 2000, holotype; Bed 145, top of bituminous shale (basal assemblage of the Sinemurian) (SMC X29333). Same scale as Figure 8; 6. Vermiceras sp., fragment of a venter (basal assemblage of the Sinemurian) (SMC X29334). Same scale as Figure 8; 7. Vermiceras elegans Bloos and Page, 2000, holotype; Bed 160 (upper Conybeari Subzone) (SMC X29335). Same scale as Figure 8; 8. Vermiceras elegans Bloos and Page, 2000; Bed 160 (upper Conybeari Subzone) (SMC X29336). Same scale as Figure 8.

have been found associated in the boundary level, a further indication of virtually continuous sedimentation.

Further studies have revealed that in almost the whole of the Northwest European Province, a gap exists between both stages and that the completeness of the stages varies within the province (Bloos, 1988; Bloos and Page, 2000). Only in rapidly subsiding troughs in western Britain was sedimentation continuous; the resultant succession is well exposed on the coasts of West Somerset (southwest England) and in Glamorgan (southern Wales). The sequence in Glamorgan is about twice as thick as that in Somerset, but the ammonite fauna in the boundary interval is very scarce and consequently the exact position of the boundary cannot be recognized.

The Somerset sequence is the only one in the province which fulfills the GSSP requirements of continuity of sedimentation, continuity of fossil record and excellent exposure. It is the most complete in the province and all faunal levels at which the Sinemurian is known to begin in other parts of the province are present. The Somerset succession consequently provides a reference against which the incompleteness of other sections can be assessed. The fauna at the
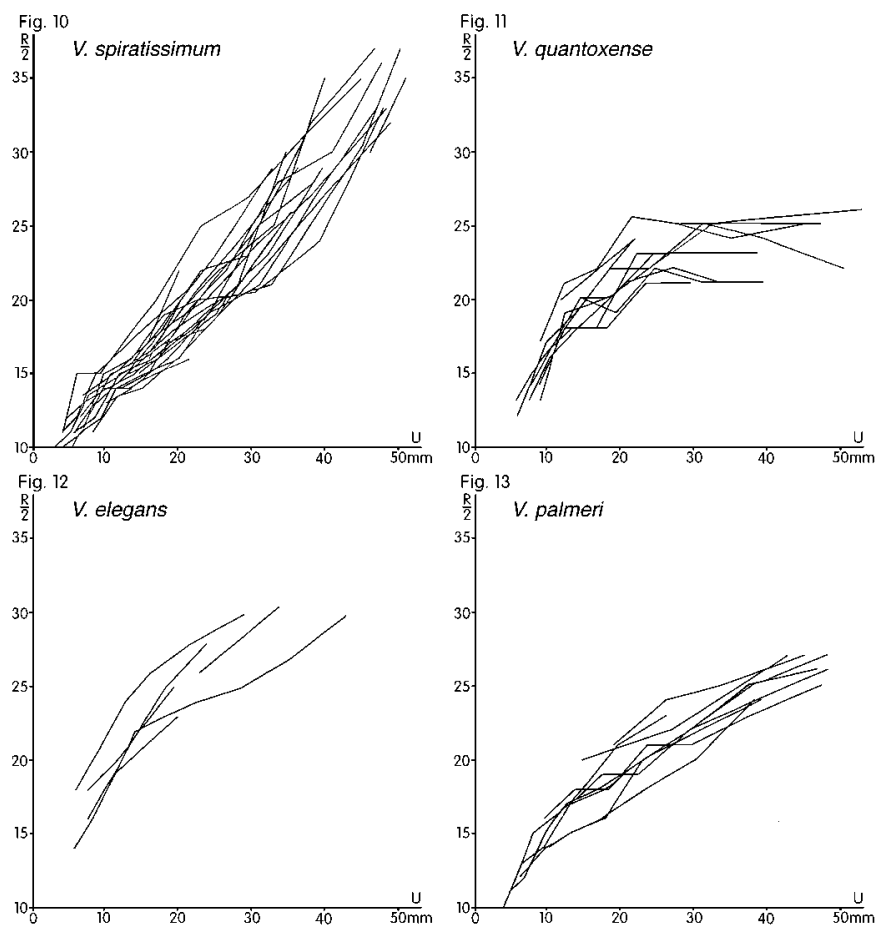

Figures 10-13 Ontogeny of ribbing in four species of Vermiceras. Rib numbers on the half whorl $(R / 2)$ in relation to the corresponding width of umbilicus $(U)$ (instead of diameter which cannot be measured on the inner whorls). Figures 11 and 13 are species from the base of the Sinemurian. Adopted from Bloos and Page (2000).

10. V. spiratissimum (SW Germany) for comparison; the development in $V$. rougemonti is essentially the same. Density of ribbing increases during ontogeny; 11 . V. quantoxense; rib numbers increase rapidly in early ontogeny but become static or even retarded in later ontogeny; 12. V. elegans; highest rib density of all known species of Vermiceras. Unlike in $V$. spiratissimum, the increase of rib numbers becomes retarded in later ontogeny; 13 . V. palmeri; trends similar to V. elegans, but the rib numbers are considerably lower.

base of the Sinemurian as recognised in Somerset is the earliest attributed to that stage, it has no confirmed correlatives elsewhere in the Northwest European Province.

Lithologically, the stage boundary is not situated at the boundary between two cycles of the Blue Lias (see above), it is situated within a bituminous shale unit (Figures 2, 4, 6). There is no recognisable break of sedimentation at the boundary. A thin concentration of fish remains facilitates location of the boundary level in the section. Most of the fish are represented by abundant scales and bones; however, small complete specimens are also known, indicating rapid burial in place.

\section{Further studies across the boundary level}

Besides ammonites, other elements of the fauna, flora and sedimentological characters of the boundary interval have also been studied, including ostracods, foraminifers, palynomorphs, magnetostratigraphy and gamma ray log (for details see Page et al., 2000).

The ostracod fauna is of low diversity (Ogmoconchella aspinata) and is not yet known well enough to recognise the stage boundary (Hart and Hylton in Page et al., 2000; Hart and Hylton, 1999). The foraminifer fauna is, however, more diverse. Lingulina tenera plex. substriata is characteristic of the latest Hettangian and the consistent appearance of Planularia inaequistriata and the 
Frondicularia terquemi plexus group is characteristic of the basal Sinemurian (Hart and Hylton in Page et al., 2000; see also Hylton, 1998, and Copestake and Johnson, 1989).

Palynomorphs are poorly preserved and, as with ostracods, are not yet stratigraphically useful across the boundary (Fitzpatrick and Hylton in Page et al., 2000). This is not surprising, however, in sections elsewhere with better preserved palynomorphs, no change from Hettangian to Sinemurian has been proved (Weiss, 1989).

Further fossil groups occur in the section (e. g. bivalves, brachiopods, echinoderms, etc.), although they have not yet been studied in detail.

Magnetostratigraphic investigations could not yet recover primary remanences, even with detailed progressive demagnetisation (Randall and Morris in Page et al., 2000), although increasing refinement of techniques may ultimately yield useful information (M. Hounslow, pers. comm. 2001).

Gamma Ray: There is a marked peak in $U$ concentration just above the stage boundary in the bituminous shale and another four metres higher (Bessa, Hesselbo and Jenkyns in Page et al., 2000). Recognition of these peaks elsewhere would naturally depend on the stratigraphical completeness of the studied section.

\section{Correlation potential}

A general difficulty for world-wide correlation is the provincialism of ammonites in the Lower Lias, especially in the upper Hettangian. The abrupt change of ammonite faunas at the stage boundary is restricted to the NW European Province. Nowhere else in the world are the ammonites of the Upper Hettangian represented by virtually only one genus (Schlotheimia) in such high diversity and frequency. Other schlotheimiids (Angulaticeras s. 1. = "Charmasseiceras") and early arietitids as well as late representatives of genera of the Middle Hettangian normally dominate the ammonite fauna of the Upper Hettangian. The genus Schlotheimia is often far less frequent and diverse and sometimes it is even absent. It is consequently difficult in general to distinguish latest Hettangian and earliest Sinemurian. In the Rotiforme Subzone, faunas are more similar world-wide and correlations offer less problems. For correlating the stage boundary interval, a fauna intermediate in character between those of the NW European and other provinces is therefore necessary.

Such an intermediate fauna exists in the Mediterranean Province, in the Marmoreum Zone of the northeastern Alps (Wähner, 1886 a, b, 1887, 1888, 1891; see also Canavari 1882, 1888), although, unfortunately, in extremely condensed deposits. The relations between both provinces in the Schlotheimiidae (genera Schlotheimia and Angulaticeras; Bloos, 1979, 1988 b) as well as in characteristic Arietitinae (Schreinbachites; Bloos, 1994, 1996; see also Guerin-Franiatte, 1990 and Donovan, 1952) show that the Marmoreum Zone does not exceed the NW European Angulata Zone; characteristic ammonites of the earliest Sinemurian do not occur either in the Angulata Zone or in the Marmoreum Zone. On basis of this correlation further ammonites of the alpine Marmoreum Zone which are not known in NW Europe become indicative of the Upper Hettangian (Gyrophioceras, Paracaloceras, Pseudaetomoceras, Ectocentrites).

The Sinemurian begins in the Alps with the Rotiforme Zone sensu Wähner (1891, 1894), condensed in a limestone bed; this bed, however, often is lacking (Wähner, 1886 a). The ammonite fauna of the Rotiforme Zone (Wähner, 1891, 1894) is very similar to that of the contemporaneous Rotiforme Subzone in the NW European Province. It contains, moreover, rare elements of the upper Conybeari Subzone, whereas representatives of the lower Conybeari Subzone are not yet known. A gap obviously exists at this level, additionally indicated by a lithological break between the Marmoreum and Rotiforme condensed beds. The similarity of faunas in the Rotiforme Zone between the Alps and NW Europe suggests that in the Conybeari Subzone faunal similarities could also be high.
The best sections in other continents are known in North and South America; Canada - Kennecott Point on the Queen Charlotte Islands (Pálfy, 1991, Pálfy et al., 1994) and probably Taseko Lake area (Frebold, 1964); USA - First Canyon in the Shoshone Mountains, Nevada (Taylor, 1990, 1998, 2000); Chile - Cerros de Cuevitas in northern Chile (v. Hillebrandt $2000 \mathrm{a}, \mathrm{b}$ ); Argentina - Arroyo Malo in the Rio Atuel valley, Province of Mendoza (Riccardi et al., 1988, 1991, v. Hillebrandt, 1990, 2000 a, b). In the boundary interval of these sections either the record of the ammonite fauna is discontinuous or preservation is too poor for detailed comparisons.

Since ammonite faunas across the stage boundary in other faunal provinces exhibit closer relations to the alpine faunas than to those of the NW European Province, a comparison with the Marmoreum Zone facilitates the recognition of the late Hettangian. For the recognition of the lower Conybeari Subzone no direct comparison is possible. The fact that the genera Metophioceras s. str. (not to be confused with large Paracaloceras) and Vermiceras s. str. (excluding the subgenus Gyrophioceras) do not occur either in the Angulata Zone or in the Marmoreum Zone may indicate that these genera would also be unlikely to appear before the beginning of the Sinemurian in other faunal provinces. Consequently, the traditional definition of the base of the Sinemurian, as in Donovan (in Dean et al., 1961), using the appearance of the genus Metophioceras, remains the best means to recognize the base of the Stage.

\section{Acknowledgements}

Establishing the most suitable candidate GSSP would not have been possible without information from many parts of the world, provided by members of the Sinemurian Boundary Working Group. These results have been published in many different journals, some of which are listed below.

A major task has been the study of ammonite faunas, including systematic revisions necessary for reliable correlations. The following collections provided material for comparison: The Bristol City Museum and Art Gallery, UK, the Natural History Museum London, UK, the Sedgwick Museum, Cambridge, UK, British Geological Survey, Keyworth, UK, the Museum of Comparative Zoology, Cambridge/Mass., USA, the Museo di Storia Naturale e del Territorio, Pisa, Italy, the Naturhistorisches Museum Wien, Vienna, the Geologische Bundesanstalt Wien, Vienna, Austria, Musée d'Histoire Naturelle de Semur, France, Musée d'Histoire Naturelle de Luxembourg, Bundesanstalt für Geowissenschaften und Rohstoffe, Berlin, Germany, and the universities of Bristol, Lyon, Vienna, Innsbruck, Munich, Tübingen, Göttingen, Hamburg, Clausthal-Zellerfeld, Berlin (TU, Humboldt). Important material was donated by the private collectors S. Gräbenstein, Ofterdingen, R. Veit, Velden, and Dr W. Riegraf, Münster, all Germany.

\section{References}

Bloos, G., 1979, Über Ammonites ventricosus Sow. und ähnliche Schlotheimiiden im tieferen Sinemurium (Unterer Lias): Paläontologische Zeitschrift, v. 53, pp.142-162.

Bloos, G., 1988 a, On the stage boundary Hettangian/Sinemurian in northwest Europe and in the north-eastern Alps: 2nd International Symposium on Jurassic Stratigraphy, v. 1, pp. 71-83.

Bloos, G., 1988 b, Ammonites marmoreus Oppel (Schlotheimiidae) im unteren Lias (angulata-Zone, depressa-Subzone) von Württemberg (Südwestdeutschland): Stuttgarter Beiträge zur Naturkunde, ser. B, no. 141 , pp. 1-47.

Bloos, G., 1994, Frühe Arietitidae (Ammonoidea) aus dem Hettangium (Angulata-Zone, Unt. Lias) von Württemberg (SW-Deutschland): Stuttgarter Beiträge zur Naturkunde, ser. B, no. 219, pp. 1-67.

Bloos, G., 1996, The Hettangian/Sinemurian stage boundary - further observations: GeoResearch Forum, v. 1-2, pp. 119-128.

Bloos, G., and Page, K.N., 2000, The proposed GSSP for the base of the Sinemurian stage near East Quantoxhead/West Somerset (SW England) — the ammonite sequence: GeoResearch Forum, v. 6, pp. 13-25. 
Canavari, M., 1882, Beiträge zur Fauna des unteren Lias von Spezia: Palaeontographica, v. 29, pp. 123-192.

Canavari, M., 1888, Contribuzioni alla fauna del Lias inferiore di Spezia: Mem. Regio Comitato geol. Italia, v. 3, pp. 57-227.

Copestake, P., and Johnson, B., 1989, The Hettangian to Toarcian (Lower Jurassic), in: Jenkins, D. G. and Murray, J. W., eds, Stratigraphical Atlas of Fossil Foraminifera. British Micropaleontological Society Series, pp. 129-272.

Corna, M., and Mouterde, R., 1988, Le Sinémurien de Semur (France): essai de biozonation pour le Sinémurien inférieur et le Lotharingien inférieur du stratotype et du Jura méridional, in, Rocha, R.B. and Soares, A.F., eds, $2^{\text {nd }}$ International Symposium on Jurassic Stratigraphy, Lisboa 1987, v. 1, pp. 101-107.

Donovan, D. T., The ammonites of the Blue Lias of the Bristol District. Part 1. Psiloceratidae and Schlotheimiidae. Part 2. Arietitidae: The Annals and Magazine of Natural History, series 12, v. 5, pp.629-655, $717-752$.

Dean, W. T., Donovan, D. T., and Howarth., M. K., 1961, The Jurassic ammonite zones and subzones of the North West European Province: Bulletin of the British Museum of Natural History, v. 4, pp. 435-505.

Frebold, H., 1967, Hettangian ammonite faunas of the Taseko Lakes area, British Columbia: Geological Survey of Canada Bulletin, v. 158, pp. 135.

Guerin-Franiatte, S., 1990, Ammonites du Lias inférieur de France. Part 2. Psiloceratidae, Schlotheimiidae et premiers Arietitidae: Mémoire du Centre díEtudes et de Recherches géologiques et hydrologiques, v. 29, pp. 1-206.

Hart, M. B., and Hylton, M. 1999. Hettangian to Sinemurian ostracod faunas from East Quantoxhead, West Somerset. Geoscience in south west England, v. 9, pp. 289-296.

Hillebrandt, A. V., 1990, Der Untere Jura im Gebiet des Rio Atuel (Provinz Mendoza, Argentinien): Neues Jahrbuch für Geologie und Paläontologie, Abhandlungen, v. 181, pp. 143-157.

Hillebrandt, A. V., 2000 a, Ammonite biostratigraphy of the Hettangian/Sinemurian boundary in South America: GeoResearch Forum, v. 6, pp. 105-117.

Hillebrandt, A. V., 2000 b, Die Ammonitenfauna des s damerikanischen Hettangium (basaler Jura): Palaeontographica, Abt. A, Teil I, v. 257, pp. 85-189, Teil II+III, v. 258, pp. 1-116.

Hylton, M. D., 1998, A preliminary analysis of the foraminifera from the Hettangian-Sinemurian boundary of East Quantoxhead, West Somerset: Geoscience in southwest England, v. 9, pp. 203-208.

Morton, N., 1971, The definition of standard Jurassic Stages: Mémoire du Bureau de Recherches géologiques et minières, v. 75, pp. 83-93.

Orbigny, A. d', 1842-1849, Paléontologie franÁaise; Terrains jurassiques: Paris, Masson, $642 \mathrm{pp}$

Page, K. N., 1995, East Quantoxhead, Somerset, England; a potential Global Stratotype Section and Point (GSSP) for the base of the Sinemurian Stage (Lower Jurassic): Proceedings of the Ussher Society, v. 9, pp. 446-450.

Page, K. N., Bloos, G., Bessa, J. L., Fitzpatrick, M., Hesselbo, S., Hylton, M., Morris, A., and Randall, D. E., 2000, East Quantoxhead, Somerset: a candidate Global Stratotype Section and Point for the base of the Sinemurian Stage (Lower Jurassic): GeoResearch Forum, v. 6, pp. 163-171.

Dr Gert Bloos is a geologist and paleontologist with the State Museum of Natural History in Stuttgart, Germany. He works on geology and stratigraphy in the Quaternary, Tertiary and Jurassic of southwestern Germany. In the Jurassic, his scientific interest is focussed on the stratigraphy of the Lower Lias. He is Convenor of the Sinemurian Boundary Working Group and Secretary of the Triassic/Jurassic Boundary Working Group of the International Subcommission on Jurassic Stratigraphy. He is also Secretary of the German Subcommission on Jurassic Stratigraphy.
Pálfy, J., 1991, Uppermost Hettangian to lowermost Pliensbachian (Lower Jurassic) biostratigraphy and ammonoid fauna of the Queen Charlotte Islands, British Columbia: Unpublished M. Sc. thesis, University of British Columbia, xii+243 pp.

Pálfy, J., P.L. Smith, P. L. and Tipper, H. W., 1994, Sinemurian (Lower Jurassic) ammonoid biostratigraphy of the Queen Charlotte Islands, Western Canada: Geobios, Mémoir spécial, v. 17, pp. 385-393.

Palmer, C. P., 1972, The Lower Lias (Lower Jurassic) between Watchet and Lilstock in North Somerset (United Kingdom): Newsletters in Stratigraphy, v. 2, pp. 1-30.

Remane, J., Basset, M. G., Cowie, J. W., Gohrbrandt, K. H., Lane, R. H., Michelsen, O., and Naiwen, W., 1996, Revised guidelines for the establishment of global chronostratigraphic standards by the International Commission on Stratigraphy (ICS): Episodes, v. 19, pp. 77-81.

Renevier, E., 1864, Notices géologiques et paléontologiques sur les Alpes Vaudoises, et les régions environnantes. I. Infralias et Zone à Avicula contorta (Ét. Rhaetien) des Alpes Vaudoises: Bulletin de la Société Vaudoise des Sciences Naturelles, Lausanne, v. 8, pp. 39-97.

Riccardi, A.C., Damborenea, S.E., Mancenido, M.O., and Ballent, S.C., 1988, Hettangiano y Sinemuriano marinos en Argentina: V Congreso Geologico Chileno, v. 2, pp. 359-373.

Riccardi, A.C., Damborenea, S.E., Mancenido, M.O., and Ballent, S.C., 1991, Hettangian and Sinemurian (Lower Jurassic) biostratigraphy of Argentina: Journal of South American Earth Sciences, v. 4, pp. 159-170.

Taylor, D.G., 1990, Two species of Paracaloceras from the Canadense Zone (Hettangian-Sinemurian stages) in Nevada (USA). Bulletin de Géologie, Lausanne, v. 309, pp. 211-219.

Taylor, D.G., 1998, Late Hettangian - Early Sinemurian (Jurassic) ammonite biochronology of the Western Cordillera, United States. Geobios, v. 31, pp. 467-497.

Taylor, D.G., 2000, The Canadensis Zone (Early Jurassic) in the Shoshone Mountains, Nevada: GeoReseach Forum, v. 6, pp. 211-223.

Wähner, F., 1886 a, Zur heteropischen Differenzierung des alpinen Lias:Verhandlungen der k. k. geologischen Reichsanstalt, v. 7, pp.168-176, 190206.

Wähner, F., 1886 b-1894, Beiträge zur Kenntnis der tieferen Zonen des unteren Lias der nordöstlichen Alpen: Beiträge zur Paläontologie von Österreich-Ungarn und des Orients, v. 4 (1886), pp.135-226, v. 5 (1887), pp.37-60, v. 6 (1888), pp.293-325, v. 8 (1891), pp.241-268, v. 9 (1894), pp. $1-54$.

Whittaker, A., and Green, G. W., 1983, Geology of the country around Weston-super-Mare. Memoir for 1:50000 geological sheet 279, New Series, with parts of sheets 263 and 295: Geological Survey of Britain; England and Wales.

Weiss, M., 1989, Die Sporenfloren aus Rät und Jura S,dwest-Deutschlands und ihre Beziehung zur Ammoniten-Stratigraphie: Palaeontographica, ser. B, v. 215, pp. 1-168.

Dr Kevin Page is a Visiting Reader in Geological Sciences at the University of Plymouth, UK, specialising on Jurassic Ammonoidea and stratigraphy in Europe, primarily in the UK and north eastern Spain. He is also a specialist in geological heritage conservation and Convener of the Geoconservation Working Group of the International Subcommission on Jurassic Stratigraphy, Associate Lecture for the Centre for Protected Landscape Studies, Birkbeck College, University of London and Fellow of the British Institute for Geological Conservation.

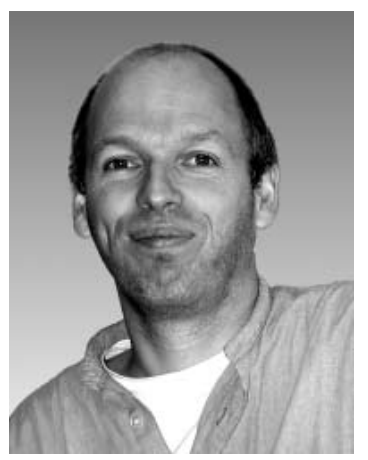

